\title{
COLONNADED STREET AT SALAMIS
}

\section{S. Hakan ÖZTANER}

\author{
Anahtar Kelimeler: Kıbris • Salamis • Sütunlu Cadde $\bullet$ Cardo $\bullet$ Roma Mimarisi \\ Keywords: Cyprus $\bullet$ Salamis $\bullet$ Colonnaded Street $\bullet$ Cardo $\bullet$ Roman Architecture
}

\begin{abstract}
:
Colonnaded Street at Salamis was found for the first time in 2002, during the excavations directed by Coşkun Özgünel and had become one of the important working areas.

During the excavation works done in the area which had been marked as 'colonnaded traces' on the city plan published by Munro and Tubbs and at its vicinity, the existence of a Colonnaded Street extending on the north - south direction and at about $40 \mathrm{~m}$ the east of the Roman Bath was determined. It was found out that there was a gate at the north end of the street and at its south, there was a Late City Wall intersecting the street. From that point, it has not yet been ascertained up to which point the street extended and terminated in the south. The total length of the street from the gate at the north to the late city wall was measured as $341 \mathrm{~m}$. The width of the unearthed parts of the street varied between $4.64-4.74 \mathrm{~m}$ at the north, $4.56-4.62 \mathrm{~m}$ towards the south, and 4.80 $4.85 \mathrm{~m}$ near the late city wall. When we look at the paving stones and the borders of the street, we can see two pavement layers indicating two different construction phases that one paved on the other. On the long lateral sides of the street, the constructions and arrangements show differences according to the related phases. While it was a colonnaded street in its first phase, the spaces between the colonnades had been covered by rubble stone walls in its second phase and it lost its character of being a colonnaded street.

The street with its width of $4.7 \mathrm{~m}$ connected the north of the city where there public buildings such as Gymnasium, Theatre, and Roman Bath were situated, to the south of the city where there were settlements; was one of the main streets of the city. The first phase of the street can be dated to the $I^{\text {st }}$ and $\mathrm{II}^{\text {nd }}$ centuries $\mathrm{AD}$ and it might be a cardo with its north-south direction. The small findings and coins found during the excavations indicated that the Colonnaded Street such as the other buildings in the City had been damaged and lost its level in the big earthquake in the IVth century $\mathrm{AD}$ and it was repaired by paving of the second phase pavement. The street connecting the north of the city to the south was probably used as a main street until the construction of the Late City Wall that was built against the Arab raids in VII th century AD.
\end{abstract}




\section{Özet: Salamis Sütunlu Caddesi}

Salamis’te, Coşkun Özgünel başkanlığındaki 2002 yllı kazı çalışmalarıyla, Roma hamamının yaklaşık $40 \mathrm{~m}$ doğusunda, Munro ve Tubbs tarafindan yayınlanan kent planında, "kolonad izleri" olarak belirtilmiş alanda ve devamında, kuzey-güney aksında uzanan bir sütunlu caddenin var olduğu saptanmıştır. Yaklaşık 204 m uzunluğundaki kısmını açığa çıkardığımız caddenin kuzey ucunda bir kapının (Kuzey Kapısı) bulunduğu, güneyde ise geç dönem surunca kesildiği tespit edilmiștir. Caddenin bu noktadan sonra güneye doğru nereye kadar uzanıp, son bulduğu henüz bilinmemektedir. Kuzey kapısından geç dönem suruna kadar olan kısımda caddenin toplam uzunluğu 341 m’ye ulaşmaktadır. Caddenin açı̆̆a çıkarılan kısımlarındaki genişliği; kuzeyde 4.64 - $4.73 \mathrm{~m}$, güneye doğru $4.56-4.62 \mathrm{~m}$, güneyde geç dönem surları yakınında ise $4.80-4.85 \mathrm{~m}$ arasında değisşen ölçülerdedir.

Caddenin blok taş döşemeleri ile bordürleri incelendiğinde, iki farklı yapım evresine işaret eden üst üste döşenmiş iki döşeme ve caddenin yan uzun kenarlarında bu evrelere göre farklilık gösteren yapılaşma ve düzenlemeler görülmektedir. 1. evresi sütunlu cadde olan caddenin 2. evresinde sütun aralarının doldurulduğu ve sütunların işlevlerini yitirdiği tespit edilmiştir.

Kentin kuzeyindeki gymnasion, tiyatro, hamam gibi kamu yapılarının bulunduğu alanla, güneyindeki yerleşim birimleri arasındaki bağlantıyı sağlayan $4.7 \mathrm{~m}$ genişliğindeki cadde kentin ana caddelerinden birisidir. Kuzey-güney aksında, cardo olabilecek bu caddenin ilk evresi M.S. 1.-2. yüzyllara tarihlendirilebilir. Sütunlu caddenin kentteki diğer yapılar gibi M.S. 4. yüzyılda meydana gelen iki büyük depremde hasar görerek düzecini kaybetmiş olduğu ve ardından 2. evre olarak tanımladığımız ikinci kat döşemesiyle yeniden kaplanarak onarıldığı kazılar sonucunda ele geçen küçük buluntu ve sikkeler yardımıyla da saptanmışırı. Cadde büyük bir olasılıkla, M.S. 7. yüzyıldaki arap akınlarına karşı inşa edilen geç dönem surlarının inşasına kadar kentin güneyi ve kuzeyini birbirine bağlayan ana cadde olarak kullanılmıştır.

In the north of Salamis, at the southeast of the Roman Bath some late settlements dated to $\mathrm{V}-\mathrm{VI}^{\text {th }}$ century AD were unearthed during the excavations in $2002^{1}$. It was noticed that the limestone column drums used in that area were reused materials. Therefore, the original place of these columns was researched. A survey was made to find the area marked as "colonnade traces" which consisted of two parallel colonnades each with six columns at the city plan published by Munro and Tubbs after the Salamis ex-

1 The excavation works in Salamis have continued since 1998 under the direction of Prof. Coşkun Özgünel from Ankara University and the chief of EMU-The Research Center of Archeological Cultural Heritages. I would like to submit my thanks to my dear professor C. Özgünel for his support and permission to this work on the Colonnaded Street at Salamis. cavations in $1890^{2}$. The upper parts of six column drums that might belong to the parallel colonnades were unearthed at about $40 \mathrm{~m}$ east of the bath and $2 \mathrm{~m}$ down of the late settlements, when the dense shrubbery was cleaned in that area.

Soon after carrying out the researches in the area to figure out the original structure to which these columns belonged, we found the existence of a colonnaded street extending at the north-south direction (Fig. 1). During the excavations between 20022004, the trenches were dug in the direction of the street and when the spaces between the trenches were completely dug and joined, the majority of the well-preserved ruins of the street were unearthed (Fig. 2).

\footnotetext{
2 Munro-Tubbs 1891, Pl. 5.
} 
It was found out that there was a gate ${ }^{3}$ at the north end of the street (Fig. 9), and at its south, there was a Late City Wall ${ }^{4}$ intersecting the street (Fig. 18). From that point, it has not yet been ascertained up to which point the street extended and terminated in the south. The total length of the street was measured as $341 \mathrm{~m}$ from the North Gate to the Late City Wall and approximately $204 \mathrm{~m}$ length of it was unearthed in the excavations. The width of the unearthed parts of the street varied between $4.64-4.73 \mathrm{~m}$ at the north, $4.56-4.62 \mathrm{~m}$ towards the south, and 4.80 - $4.85 \mathrm{~m}$ near the Late City Wall.

When we examined the paving stones and the borders of the street, we noticed that two pavement layers indicating two different construction stages were paved one on the other and some arrangements and constructions that differed according to these stages observed on the long lateral sides of the road.

The pavement at the bottom which was paved earlier that we identified it as the first phase, was preserved along a part of $191 \mathrm{~m}$, but it could only be seen on a part of $113 \mathrm{~m}$ of the street where the second phase pavements on it were dismantled. Throughout

\footnotetext{
3 The gate named "North Gate" unearthed in the excavation works in 2003. This gate bordering the street at the north had an opening of $3.62 \mathrm{~m}$ on the street and was constructed in two parallel wall rows at a distance of $5.65 \mathrm{~m}$ from each other. The total length of the gate wall was $15.50 \mathrm{~m}$ with the door opening in the middle. It was $0.73 \mathrm{~m}$ thick. It had an "isodomos rectagonal" wall structure of which the two walls at the south at the heights of $0.40-0.80 \mathrm{~m}$ and the two walls at the north at the heights of 1.67-1.78 $\mathrm{m}$ have been preserved. The gate resembles a "tetrapylon" in its form. The gate opening at the north wall row had been filled by a wall before the construction of the second phase, and therefore it was assumed that the gate had been used during the first phase of the colonnaded street.

4 Karageorghis 1969, 197; Pouilloux 1980, 36-38.
}

the excavated parts of the street, we observed that the first phase pavement was also dismantled at a part of about $13 \mathrm{~m}$.

The first phase paving stones placed horizontally to the course of the street in regular rows at the east-west direction with the widths varied between 0.40 and $0.50 \mathrm{~m}$. They were cut of yellowish, calc-arenitic, gritty limestone in narrow and long rectangular form with the lengths varied between 0.55 and $1.10 \mathrm{~m}$ and the thickness of about $0.15 \mathrm{~m}$. No mortar was used between them for binding (Fig. 3).

When we studied the ground under the first phase pavement, a foundation layer varied between 0.25 and $0.30 \mathrm{~m}$ thicknesses was determined. On the reddish natural soil there was a quite stiff ground mixed with pebble and lime mortar with 0.05 and 0.07 $\mathrm{m}$ varied thicknesses. This layer on the compressed natural soil most probably was a statumen, which was used specially against water leakage at the foundations of the floors or the walls. On it, there was a sandy layer with a thickness of about $0.15-0.20$ $\mathrm{m}$, which is composed of clay and lime could be defined as a rudus ${ }^{6}$. Paving stones were placed on this layer. Under some of the paving stones, some small pebbles mixed with lime mortar were laid down with the aim of leveling to a thickness of $0.05-0.06 \mathrm{~m}$.

Throughout the street, the limestone blocks bordering the first phase pavement on both sides at the same level with the pavement varied between $0.64-0.68 \mathrm{~m}$ in length and $0.37-0.56 \mathrm{~m}$ in width. There was no ditch-

Chevallier 1976, 86

ibid, 86. 
ing system at the borders to drain the rainwater.

At the north part of the street, the bottom drums of 15 columns were found in situ or slightly away from their places, which belonged to the two colonnades, each consisting of 11 columns that were placed opposite to each other as bordering the long east and west sides of the street. The inter-axial dimensions of the columns ranged between 2.24 and $2.38 \mathrm{~m}$. The bottom drums of the columns were placed directly on the eastwest side borders of the first phase pavement.

The diameters of these unfluted column drums that were cut of a large porous limestone were around $0.60-0.65 \mathrm{~m}$ and their height varies between 0.70 and $1.30 \mathrm{~m}$ in general. There were socket holes on the top and bottom of the preserved column drums at different dimensions of $0.12 \times 0.12 \mathrm{~m}$ and $0.16 \times 0.16 \mathrm{~m}$, which possibly belonged to timber dowels to bind the drums to each other.

During the excavations at the north part of the street, ten Doric limestone column capitals were found, of which two were utilized as reused materials in the wall construction and the others were embedded in the filled soil (Fig. 4). The column capitals with 0.27 $0.345 \mathrm{~m}$ heights had generally a square abacus with dimensions of $0.58 \times 0.59 \mathrm{~m}, 0.62 \times$ $0.62 \mathrm{~m}, 0.65 \times 0.66 \mathrm{~m}, 0.73 \times 0.73 \mathrm{~m}$, with a bottom diameter ranging between 0.49 $0.56 \mathrm{~m}$. They had a double annulet on their echinus with varying gradients of 20 to 32 degrees. On some of the capitals, we could see stucco-covering traces. We observed that the stucco covering on the capital numbered DC-8 was preserved in good condition comparing to the others. Its ech- inus profile with double annulet on the limestone was covered with stucco later and turned into a single large moulding. It was observed that the broken part on the bottom surface of this capital was repaired by filling with stucco (Fig. 5).

On the preserved top and bottom parts of the Doric column capitals, there were also socket holes at varying dimensions between $0.10 \times 0.10 \mathrm{~m}$ and $0.13 \times 0.13 \mathrm{~m}$, which possibly belonged to timber dowels similar to those, which exist on the column drums.

Placement of the columns directly on the first phase pavement borders of the street without bases, and the Doric column capitals most probably belonged to those columns indicated that there were porticos in Doric order at each side of the street (Fig. 6).

Any element, which might belong to the porticos, could not be found during the surveys performed in close vicinity at the east to west sides of the street. When the preserved elements are unearthed in the further excavations, we will be able to obtain more information about the porticos and the constructions near the street. By taking into consideration the studies on the existing column drums and the Doric capitals, a restitution proposal $^{7}$ was prepared (Fig. 7) related to the first phase of the street and its porticos, although no elements belonging to their upper structures have been found yet. In the same proportions given by Vitruvius for the Doric order, the heights of the Doric capitals of the

\footnotetext{
Depending on this proposal, within the restoration works in 2005, the first unearthed column in the trench belonged to the west colonnade was erected to determine column height by placing three column drums and a capital on the in situ bottom drum of the column.
} 
street were equal to the half of the bottom diameter of their columns. In accordance with the proportions given by Vitruvius that the Doric columns heights must be equal to sevenfold their bottom diameters ${ }^{8}$, we could calculate the heights of the columns of the street as approximately $4.4 \mathrm{~m}$, based on their bottom diameters of $0.63 \mathrm{~m}$.

As it was observed on the preserved stuccos at some of the Doric capitals and on the unearthed fluted stucco parts in the excavations, we found out that the columns were also covered with stucco similar to that on the capitals and fluted. However, changing of the double annulet profile on the echinus of the limestone capitals into a single annulet by the process of covering with stucco brought to mind the question of when that process had realized. The process of covering with stucco would not have taken place at the same time as the construction of the porticos, due to the needlessness of carving and working on the limestone capitals echinus profiles that would not seen under the stucco covering. Therefore, it is thought that the limestone capitals with double annulets might have been used without stucco covering at least for a certain time, and then it might have been covered later when a repair or a restoration was required. However, we noticed that the echinus profile with single annulet on the stucco- covered capitals was carved directly on stone at DC.10 numbered limestone capital (Fig. 4). This sample showed that some limestone capitals, which were carved according to this new profile, might have also been used together with the other stucco-covered capitals for the purposes of reparation or construction. An-

8 Gros 1992, 7. other possibility was that, those Doric capitals might have been brought from some other demolished or abandoned building and have been reused in the construction of the porticos. Besides the reused capitals, also the new ones produced at the similar types. The traces of the stucco repairs on the capitals indicated that the broken parts were repaired with stucco, and then were placed on the limestone columns and coated together with stucco in order to give them a marble appearance.

The upper pavement layer of the street was identified as the second phase pavement, which remained unharmed in a part of 66 $\mathrm{m}$ of the street. This pavement was laid over the first phase pavement of which the level had probably been distorted by an earthquake. Therefore, the second phase pavement was paved after leveling of the ground of the first phase pavement with a white lime mortar of a thickness of $0.10-$ $0.20 \mathrm{~m}$. At the parts where the level of the first phase pavements was highly distorted and collapsed, there was another filling that had been leveled and compressed with lime, sand and pebbles under the lime mortar. The second phase paving stones were graygreenish calc arenitic sandy stones that were regularly cut at widths varying between 0.40 $-0.90 \mathrm{~m}$, and $0.40-1.20 \mathrm{~m}$ length and 0.19 - $0.23 \mathrm{~m}$ thick on the north part (Figs. 9-10) and $0.06-0.12 \mathrm{~m}$ thick on the south part (Figs. 12-13) of the street in general. The paving stones of the second phase were much softer and weaker than the first phase paving stones. Their joints were plastered with lime mortars. The second phase paving stones were also paved generally in rows extending in the east-west direction. However, unlike the first phase pavement, 
the width of the rows was not of the same dimensions. Due to the irregular paving order of the stones lengthwise or widthwise, the lengths of the rows had different dimensions.

At a later date, probably during the paving of the second phase pavements, the rubble stone walls with soil or lime mortar were constructed between the columns to serve as a border. These walls with $0.40-0.65 \mathrm{~m}$ thickness that covered the spaces between the columns on both sides of the street were preserved at the heights of approximately varied between 0.30 and $0.70 \mathrm{~m}$ at the west side and $0-0.50 \mathrm{~m}$ at the east side. Two Doric capitals and twelve column drums belonging to the first phase of the street were employed in the construction of these walls as reused materials. Two of these columns were used on the west side and ten of them (two of them in hexagonal forms) on the east side of the street (Fig. 8).

The column rows which could be followed through eleven rows without interruption within the rubble stone wall on the north part of the street could not be seen in the south direction, except at some places where they were utilized as reused materials.

This column row and the low rubble stone wall at the west side of the street were followed by another wall that was constructed partly with cut stone blocks, partly with rubble stones of which the faces were smoothed and with mortar. This wall starts from $59 \mathrm{~m}$ south of the north end of the street and extends for $30 \mathrm{~m}$. This wall might belong to a later building, which bordered the street on the west side. The north part of the wall was preserved up to $1.35 \mathrm{~m}$ height and about $17 \mathrm{~m}$ length. It joined the south part $0.43 \mathrm{~m}$ west of its southern cor- ner. After that point, the street and the wall turned slightly to the southwest. The deviation in the direction of the street was clearly visible at that corner and the paving stones of the second phase pavement were laid according to that corner of the wall.

At $3.35 \mathrm{~m}$ north of this corner, there was a trough placed on the second phase pavement of the street that was preserved up to a $0.57 \mathrm{~m}$ height with the dimensions of 5.63 x $0.63 \mathrm{~m}$ (Fig. 11). The inner faces of the trough were plastered with a hydraulic mortar. However, there was no archeological evidence to indicate that this trough was a part of a fountain. The second phase pavement of the street was used as the floor of the trough, and therefore it was thought that the trough was used in the later phase of the street, and was probably constructed to meet the water needs of the animals passing through the street.

At $2.15 \mathrm{~m}$ south of the corner, there was a door opening on the wall with a width of $1.04 \mathrm{~m}$. The opening between the door casings were filled with a rubble stone wall of which the two rows were preserved. We could see a similar case at another door with a $1.00 \mathrm{~m}$ width which was situated on the east wall at $14 \mathrm{~m}$ southeast across; the opening between that door's casings were also filled.

In the south part of the street, the cut stone blocks (at $0.40 \times 0.60-0.80 \mathrm{~m}$ dimensions in general) of the walls bordering the second phase pavement on both sides of the street, were preserved at the foundation level or in a level of two rows (Fig. 12).

From the North Gate to the Late City Wall at the south, the phases that we observed on the unearthed parts of the street were as stated below. 
In the north part of the street, inside the North Gate and at the part $6.65 \mathrm{~m}$ south of it, there was a second phase pavement (Fig. 9), and at its continuation to the south, there was a first phase pavement of about $40 \mathrm{~m}$. In this part, some of the second phase paving stones preserved through the west border of the street in a single line of $5 \mathrm{~m}, 1$ $\mathrm{m}$ and $7 \mathrm{~m}$ long. In this section, there was a late period canal, which cut the street at the southwest - northeast direction, and narrowed in this direction from a width of 0.50 $\mathrm{m}$ to $0.13 \mathrm{~m}$, with a depth of $1.45 \mathrm{~m}$ and a length of $4.40 \mathrm{~m}$. The canal passed across the street, cutting the first phase pavement at a level under the second phase pavement (Fig. 14-A).

In the following section of $13 \mathrm{~m}$, there was a leveling mortar layer used under the second phase pavement, of which the stones were removed except one single line preserved along $5 \mathrm{~m}$ on the east side. At the continuation of this mortar layer, a second phase pavement was preserved along $40 \mathrm{~m}$ (Figs. 10, 14-B). In the south of this part where the modern asphalt road crossed the street, we could generally see the first phase paving stones along $76 \mathrm{~m}$ to the south, but at some parts, we could also see the second phase paving stones (Fig. 15). From the point where the trenches were dug to $14 \mathrm{~m}$ south and at some control trenches that were partly dug $90 \mathrm{~m}$ along the street, it was seen that the first phase paving stones of the street had also been removed'. The cause of this destruction of the street could

\footnotetext{
9 The discovery of the ceramic pieces belonging to the archaic period in the trenches under the pavement layer indicated that the early period settlements at the south of the city had expanded up to these areas. According to the stratification, The Roman Period came on top of the Archaic Period.
}

probably be explained by the reuse of the paving stones in other structures as construction materials when the street had lost its function as time passed.

On the other hand, following this destroyed part, at the trenches dug $57 \mathrm{~m}$ towards the Late City Wall, we could observe the second phase pavement which was preserved here for a length of $19 \mathrm{~m}$ and almost covered the whole width of the street. The first phase paving stones could also be seen under the dismantled parts of the second phase pavement (Fig. 16). We observed that at the trench dug near the Late City Wall, which intersected the street, the second phase pavement was completely preserved. This part was the last point of the street, which we could follow to the south (Fig. 18).

When we look at the thickness of the pavement $(0.15-0.20 \mathrm{~m})$, the prepared base for the pavement and the wheel ruts observed on some of the first and second phase paving stones, (Figs. 16, 17), we could conclude that the street was open to the vehicle traffic $^{10}$. The wheel-ruts of the carts on the paving stones showed that the two phases of the street were used for long periods. When we examined the wheel ruts that could be observed clearly at the south of the street near the late city walls, we determined that these ruts were caused by carts with $1.3-1.35 \mathrm{~m}$ wheel dimensions from

\footnotetext{
10 Certain differences in the pavements can be seen according to the type of the circulation on it. The pavements which were only for the use of the pedestrians on the public areas that were closed to vehicle traffic, had been built on a thin layer on very carefully leveled ground. However, the pavement stones on the street were laid by placing them thoroughly on one or two layers of coarse strong pebbles, graveled pebbles and a gravel ground against the damaging and spoiling effects of the vehicles on the pavement.
} 
axle to axle. Although a fixed common axle dimension was not observed, the axel dimensions of the carts, generally conformed to the average axle-to-axle dimension, which is equal to $1.3 \mathrm{~m}^{11}$. The street was built with a width of $4.7 \mathrm{~m}$, which could easily allow passing two carts or even three carts having these axle dimensions at the same time. As the paving stones with wheel-ruts usually seen at the middle of the street, it can be assumed that the vehicle traffic usually circulated down the middle of the street.

The width of the streets varied from city to city. Main streets in Pompei had almost the same carriageway width $(4 \mathrm{~m})$ and a distance of $8 \mathrm{~m}$ from wall to wall. The variation of nearly $0.20 \mathrm{~m}$ in the width of the roads could be seen in Abondance, Stabies, Nola and Fortuna. In Mercure this width was increased with a roadway width of $4.50 \mathrm{~m}$ and a total width of $9 \mathrm{~m}$. At Paestum, at the crossroads near the forum the road width for the cardo was $5.30 \mathrm{~m}$, and the width of the road, which cut it with a right angle, was $4.80 \mathrm{~m}$. The width of the roads varied between 4 and $5 \mathrm{~m}$ at Ostia, $4.50 \mathrm{~m}$ at Vaison and $5 \mathrm{~m}$ at Timgad $^{12}$.

The colonnaded street of Salamis might be one of the principle arteries of the city considering its similar dimensions with the other equivalent streets and its width being adequate to meet the traffic requirements of main arteries. The decumanus at the east-west direction and the cardo at the north-south direction were the two main roads that crossed each other at a right angle, and they were the essential elements of the Roman city planning and urbanization.

\footnotetext{
11 Adam 1994, 279.

12 For all given examples see, Adam 1994, 279 - 280.
}

There is a high probability that this principle street in Salamis, which passed through the city center on the north-south direction and connected the north (where there public buildings such as gymnasium, theatre and roman bath were situated), to the south of the city (where there were settlements) might have been a cardo.

The colonnaded street had a very important role in the history and urbanization of the city of Salamis together with another street under the sea ${ }^{13}$, which was found in 1974 during the underwater investigations in the harbor, at the north-south direction about $100 \mathrm{~m}$ in length and $5.20 \mathrm{~m}$ in width. Its extension on the shore has not yet been determined.

\section{Dating}

It is known that very severe earthquakes hit some regions of Cyprus for several times in Roman Period. Some of them were very big earthquakes, which occurred in $\mathrm{AD}$ 76-7 $77^{14}$ that caused big loss of lives and properties $^{15}$. We understand from the inscriptions that the emperors Trajan and Hadrian who as the protector of the city contributed to the costs of the reconstruction and repair activities in the city following the earthquakes occurred in $\mathrm{I}^{\text {st }}$ century AD. ${ }^{16}$ The earthquakes, which occurred in $\mathrm{IV}^{\text {th }}$ century $\mathrm{AD}$ destroyed Salamis to a great extent and caused big losses. The emperor Constantius II (AD 337-361) exempted the citizens from all kinds of taxes for four years, to give them an opportunity to be able to rebuild their city. The name of this newly es-

\footnotetext{
13 Flemming 1974, 166 -169.

14 Bedevi 1965, 56.

15 Karageorghis 1969, 190.

16 Karageorghis 1962, 399.
} 
tablished Christian city was changed to Constantia in honour of the emperor. The scale of this new city was almost the same as that of Salamis and the public buildings such as gymnasium ${ }^{17}$ and roman bath ${ }^{18}$ were repaired and reused. In the VII ${ }^{\text {th }}$ century $\mathrm{AD}$, a late city wall surrounding a small area had been built at the centre of the Constantia, for protection against Arab raids. The column drums and blocks seen on the exterior faces of the walls indicated that the materials, which were brought here from the demolished or abandoned buildings in the city, were reused in the construction of the city walls. The Arab invasion terminated the life of Salamis. For the following several centuries, the occupiers lived among these ruins ${ }^{19}$. After this, the city served as a stone quarry used for the construction of the Famagousta in the middle ages, and many architectural elements of the ancient city were used in various buildings such as on the gate of Venice Palace ${ }^{20}$.

Within this historical process, the Augustan period when the repair and the construction activities were seen at the north of the city could be the earliest date for the first construction phase of this street, which might be a cardo with its very important role in the life and the planning of the city. The reconstruction activities at the north of the city, such as; rebuilding of the gymnasium as a bath-gymnasium complex ${ }^{21}$, and construction of the theatre ${ }^{22}$ after an earthquake at the beginning of the $\mathrm{I}^{\text {st }}$ century $\mathrm{AD}$; the repair of many public buildings including the

\footnotetext{
17 Karageorghis 1982, 187 - 189.

18 Coşkun 2007, 121.

9 Karageorghis 1969, 16.

20 Cesnola 1878, 194; Karageorghis 1969, 16-17.

21 Karageorghis 1969, 168

22 Karageorghis 1963, 52.
}

theatre by an important citizen called Servius Pancles ${ }^{23}$ after the earthquakes in $\mathrm{AD}$ 76-77; the contributions made for rebuilding of the city and construction activities during the period of emperors Trajan and Hadrian and also the reconstruction of the public buildings such as bath-gymnasium, theatre, stadium and roman bath increased the importance of this part of the city. Therefore, the construction of a main street connecting the north to the south of the city might have become necessary. According to this, the street might have been constructed sometime between the end of the $I^{\text {st }}$ Century AD and the $\mathrm{II}^{\text {nd }}$ century AD.

Meantime, the $\mathrm{II}^{\text {nd }}$ century AD was a period that the colonnaded streets became widespread as was also seen in the eastern provinces like Asia Minor and Syria ${ }^{24}$. The colonnaded streets, such as, cardo in ApameaSyria ${ }^{25}$ that passed through the city with a length of nearly $2 \mathrm{~km}$, in Bostra ${ }^{26}$ and Palmyra $^{27}$, and in many of the cities in AsiaMinor like Hierapolis ${ }^{28}$, Tripolis $^{29}$, Pompeiopolis $^{30}$, Side $^{31}$, Perge $^{32}$, Cremna $^{33}$, Ephesus $^{34}$ became the main structures and ornamental elements of the city as a new component of the monumental architecrethe understood from the existing ruins that the colonnaded street in Salamis was one of the examples of this widespread architec-

\footnotetext{
23 Karageorghis 1962, 399.

24 Crema 1959, 349; Gros 1996, 106.

25 Butcher 2003, $244-245$.

26 Gros 1996, 105.

27 Lassus 1976, 175 - 189

28 De Bernardi Ferrero 1993, 96 - 97.

29 Ceylan 1995, $160-162$.

30 Peschlow - Bindokat 1975, 387 - 391.

31 Mansel 1978, 21 - 30.

32 Heinzelmann 2003, 197 - 220; Mansel 1975, 77.

33 Mitchell - Waelkens 1987, 46.

34 Gros 1996, 106.
} 
ture in its first phase, but in its second phase it lost the characteristics of a colonnaded street. The excavations indicated that a second layer, which we identified as the second phase pavement, was constructed on the first phase pavement. In this phase, the spaces between the columns were covered with a rubble stone wall and some of the overthrown column drums and capitals belonging to the street had been utilized in the construction of the wall as reused materials. The two big earthquakes in Salamis in the years AD 332-342 might have caused the overthrown of the columns and distortion on the level of the pavement of the street like the other destroyed buildings in the city. Small findings and coins dated to the period of Emperor Constantinus and Emperor Constans between AD 330-350, which were found in the filling between the second layer pavement and the first phase paving, indicated a terminus antequem for the repair of the street. They also showed that this repair might be connected to the construction activities done after the earthquake in the period of Constantius II.

Taking into consideration the blockage of the street at the south by the Late City Wall that was built against the Arab raids, we assume that the last period when the street functioned as a main artery connecting the south and the north of the city could be as late as the VII ${ }^{\text {th }}$ century AD.

\author{
Dr. Serdar Hakan Öztaner \\ Ankara University \\ Faculty of Letters \\ Department of Archaeology \\ 06100 Sihhiye Ankara-TURKEY \\ e-mail: oztaner@humanity.ankara.edu.tr
}




\section{List of Figures:}

Figure 1. The colonnaded street, the north gate and the Roman Bath, view of the area from the east.

Figure 2. The Salamis Ancient City Plan.

Figure 3. The north part of the Colonnaded Street (A), view from the north.

Figure 4. The profile drawings of the Doric capitals belonged to the colonnaded street.

Figure 5. DC.8 numbered Doric capital with stucco repair and covering traces on it.

Figure 6. The north part of the colonnaded street (A) and the north gate, view from the south.

Figure 7. The restitution model of The Colonnaded Street.

Figure 8. The North part of the colonnaded street (A), the wall of reused materials and rubble stones built between the columns, view from the south.

Figure 9. The street-second phase pavements and the north gate, view from the north.

Figure 10. The north part (B) and the south end of the street, the second phase pavement, the western border wall, and view from the south.

Figure 11. The north part of the street (B) the second phase pavement, the west border wall and the trough, view from the north.

Figure 12. The south part of the street $(\mathrm{A})$ the first and the second phase pavements, view from the north.

Figure 13. The south part of the street (A), the first and the second phase pavements, view from the north.

Figure 14. The north part of the street (A-B) plan.

Figure 15. The south part of the street (A-B) plan.

Figure 16. The south part of the street (C) plan Figure 17. The south part of the street (C), the wheel ruts on the second phase pavement, and view from the north.

Figure 18. The second phase of the street, which the late city walls cut it at its south, a view from the east. 


\section{BIBLIOGRAPHY}

Adam 1994

Bedevi 1965

Butcher 2003

Cesnola 1878

Ceylan 1995

Coşkun 2007

Crema 1959

Chevallier 1976

De Bernardi Ferrero 1993

Flemming 1962

Gros 1992

Gros 1996

Heinzelmann 2003

Karageorghis 1962

Karageorghis 1963

Karageorghis 1969

Karageorghis 1982

Lassus 1976

Mansel 1975

Mansel 1978

Mitchell - Waelkens 1987
J. P. Adam, Roman Building, Materials and Techniques (1994).

V. Bedevi, Kıbrıs Taribi: Bașlangıcindan Zamanmıza Kadar, Kıbrıs Türk Tarih Kurumu Yayınları No. 1 (1965).

K.Butcher, Roman Syria (2003).

L. P. di Cesnola, Cyprus, Its Ancient Cities, Tombs and Temples (1878).

A. Ceylan, "Tripolis Sütunlu Caddesinde Yapılan Kazı ve Temizlik Çalışmaları", MKKS 5, 25-28 Nisan 1994 Didim (1995) 159-170.

A. Coşkun, "On the Planning and Dating of the Roman Bath at Salamis, Cyprus", E. Öztepe - M. Kadioğlu (edts.), Patronvs, Coṣkun Özgünel'e 65. Yas Armağani, Festschrift für Coskeun Özgünel zum 65.Geburtstag (2007) 119-126.

L. Crema, L'Architettura Romana. Enciclopedia Classica, III, 12,1 (1959)

R. Chevallier, Roman Roads (1976).

D. De Bernardi Ferrero, "Hierapolis", Arslantepe, Hierapolis, Iasos, Kyme Türkiye'deki İtalyan Kazıları (1993)70-119.

N. Flemming, "Report of Preliminary underwater investigations at Salamis, Cyprus", RDAC 1974, 163-173.

P. Gros, Vitruve, De l'Architecture, livre IV, Collection des Universités de France (1992).

P. Gros, L'Architecture Romaine du Début du IIIe siècle av.J.C. à la Fin du Haut-Empire 1 Les Monuments Publics (1996).

M. Heinzelmann, "Städtekonkurrenz und kommunaler Bürgersinn. Die Säulenstraße von Perge als Beispiel monumentaler Stadtgestaltung durch kollektiven Euergetismus", $A A$ 2003, 1. Halbband, 2003, 197-220.

V. Karageorghis, "Fouilles de Salamine”, BCH 86, 1962, 396-405.

V. Karageorghis, "Excavations at Salamis,1963", RDAC 1963, 5255.

V. Karageorghis, Salamis in Cyprus, Homeric, Hellenistic and Roman (1969).

V. Karageorghis, Cyprus from the Stone Age to the Romans (1982).

J. Lassus, "Quelques Remarques sur les Rues à Portiques", Palmyre. Bilan et Perspectives (1976) 175-189.

A.M. Mansel, "Bericht über Ausgrabungen und Untersuchungen in Pamphylien in den Jahren 1957-1972", AA 1975, 49-96.

A.M. Mansel, Side 1947-1966 Yillar Kaz̨lar ve Araștrmalarmin Sonuçları (1978).

S. Mitchell - M. Waelkens, "Sagalassus and Cremna 1986", AnatSt 37, 1987, 37-47. 
Munro - Tubbs 1891

Peschlow-Bindokat 1975

Pouilloux 1969

Pouilloux 1980
J. A. R. Munro - H. A. Tubbs, "Excavation in Cyprus 1890, Third Season's Work, Salamis", JHS 12, 1891, 59-198.

A. Peschlow-Bindokat, "Zur Säulenstrasse von Pompeiopolis in Kilikien" IstMitt 25, 1975, 373-391.

J. Pouilloux, "Fouilles à Salamine de Chypre (Mission Française 1964-1968)", RDAC 1969, 43-55.

J. Pouilloux, "Présentation du site", Salamine de Chypre Histoire et Archéologie Colloques internationaux CNRS (1980) 33-42. 


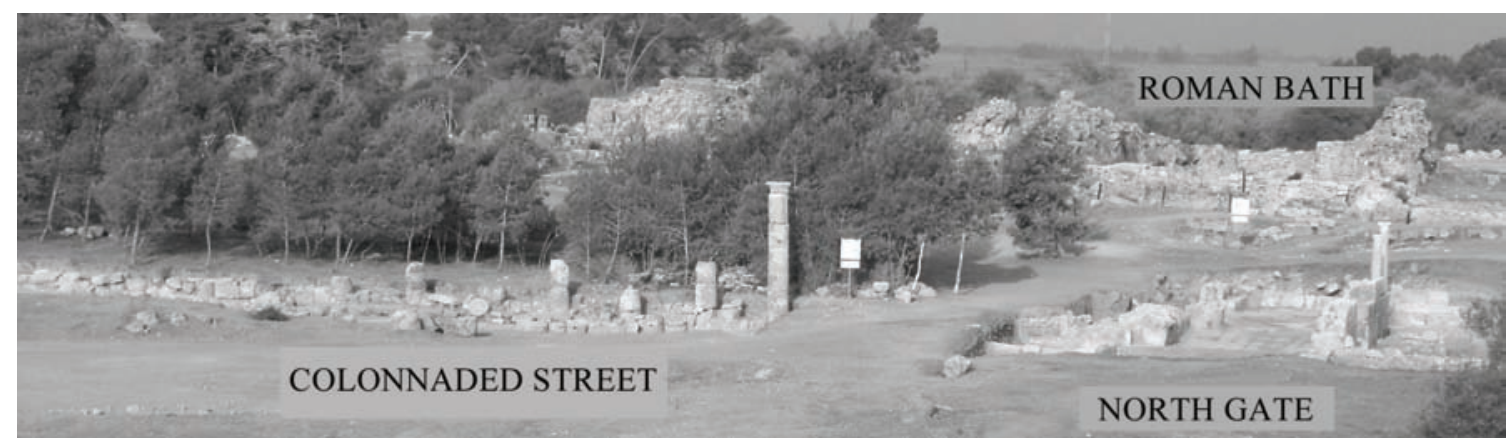

Figure 1

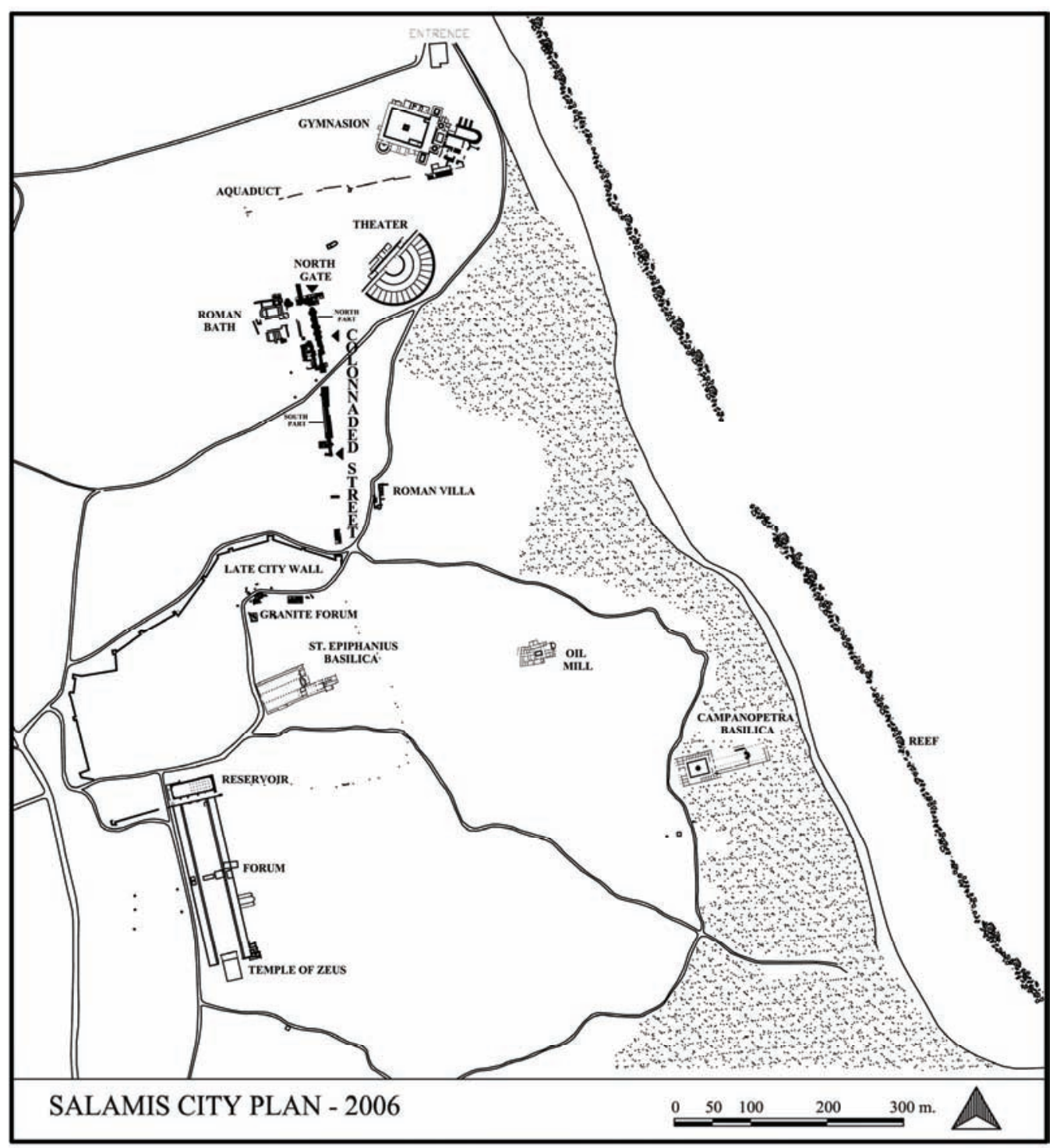




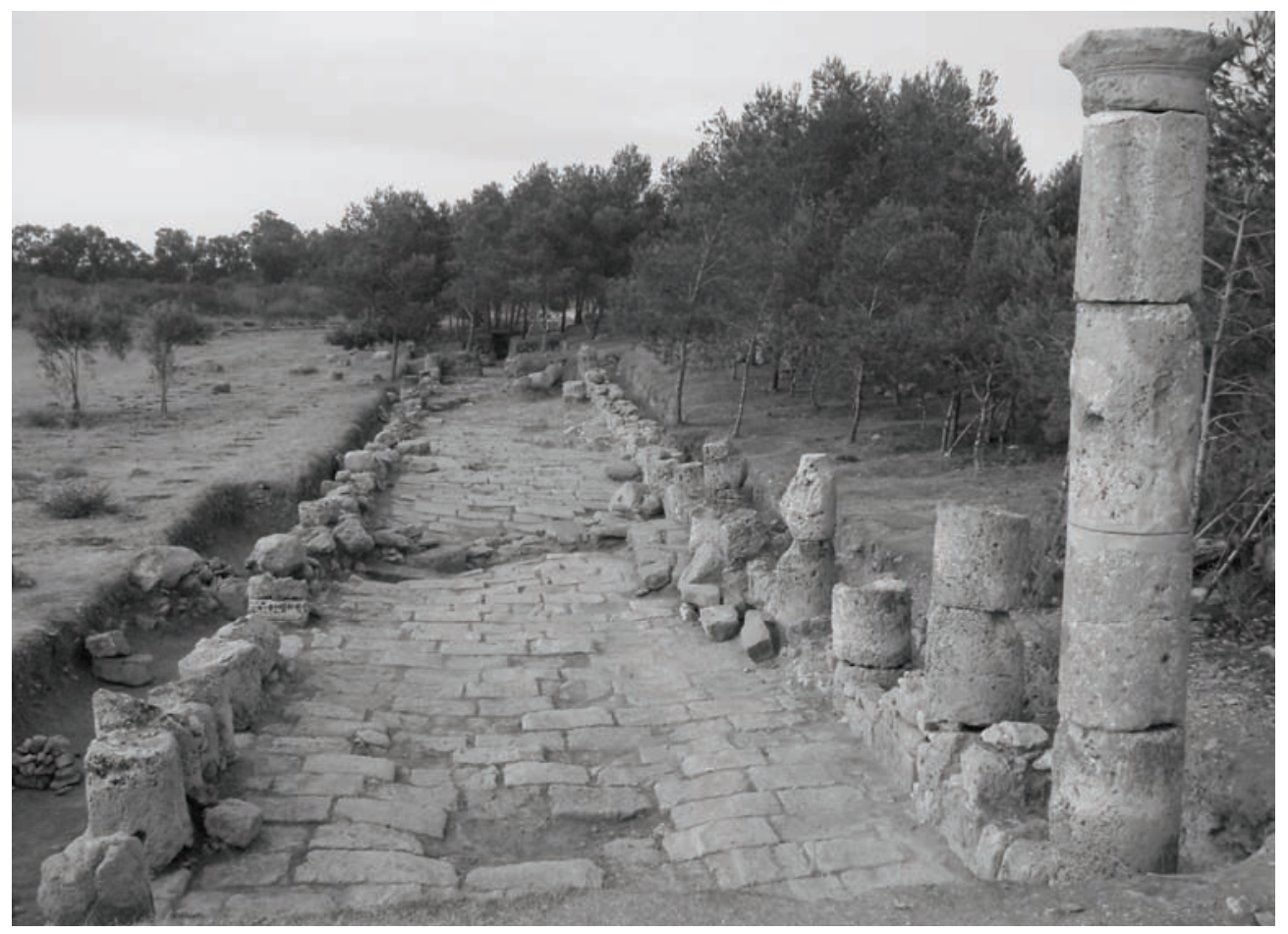

Figure 3

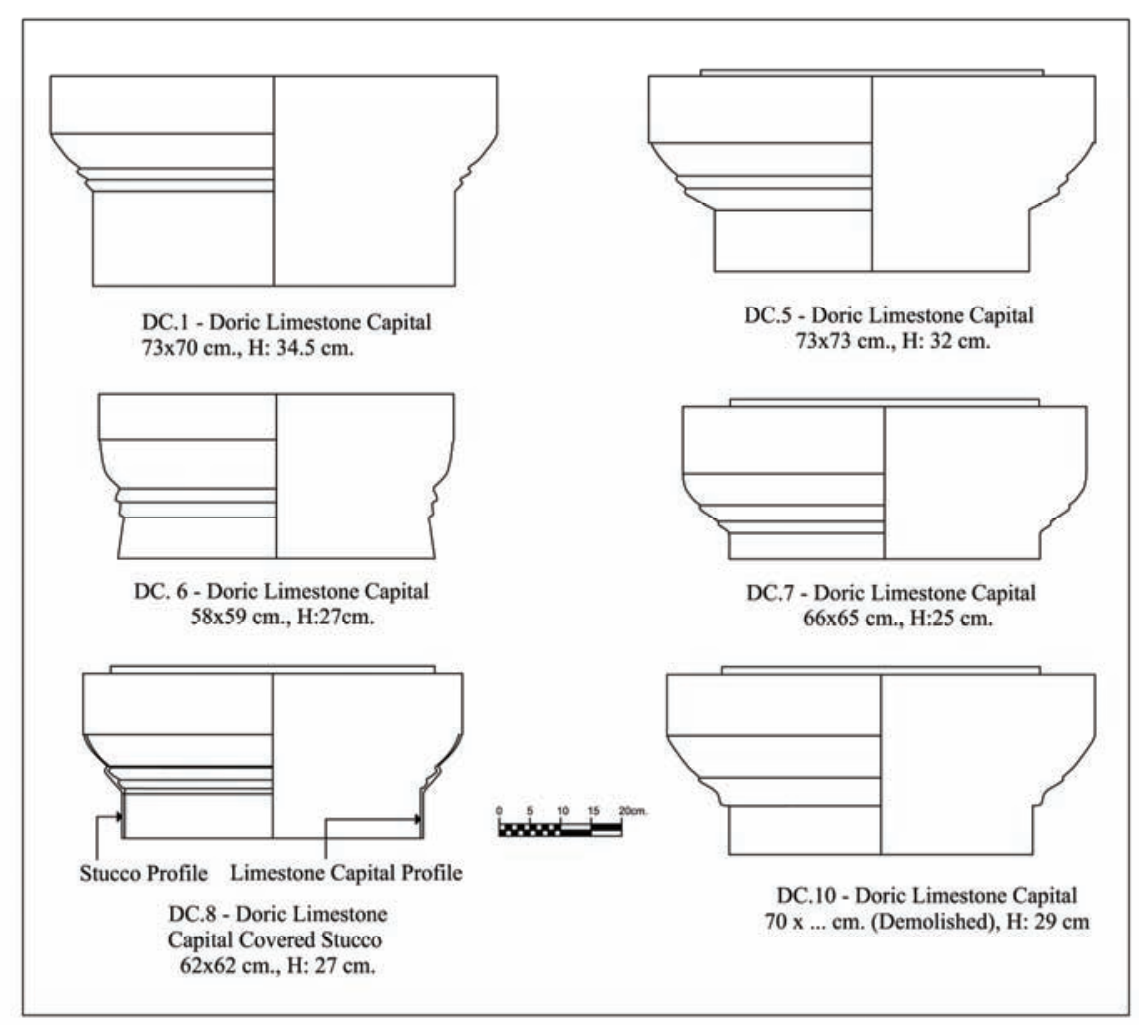

Figure 4 


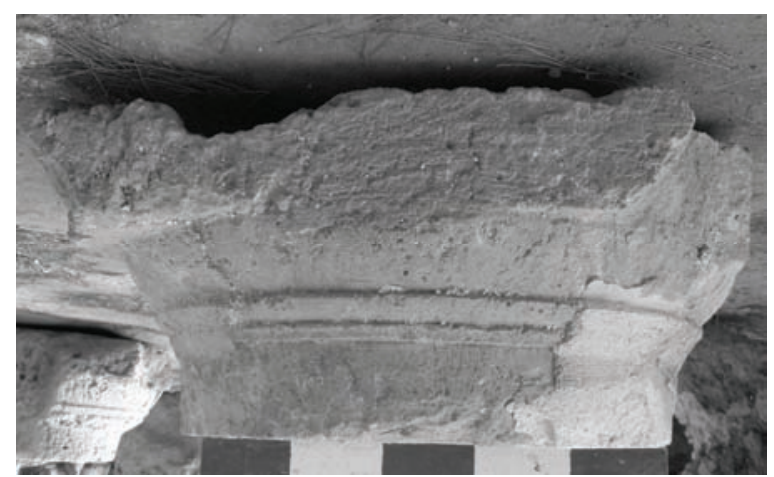

Figure 5

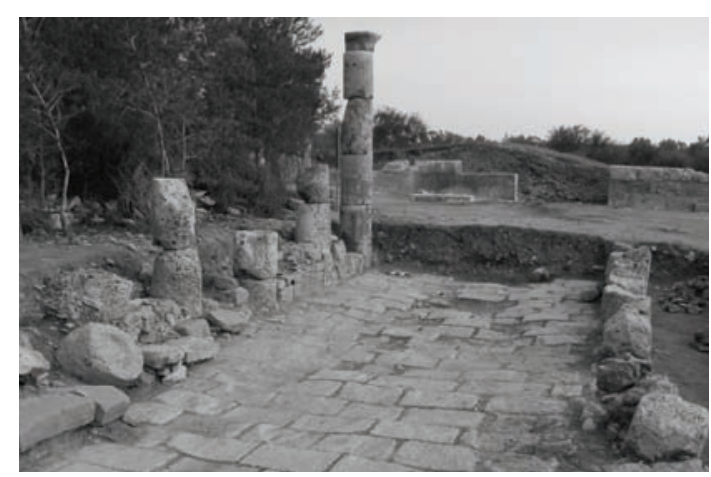

Figure 6
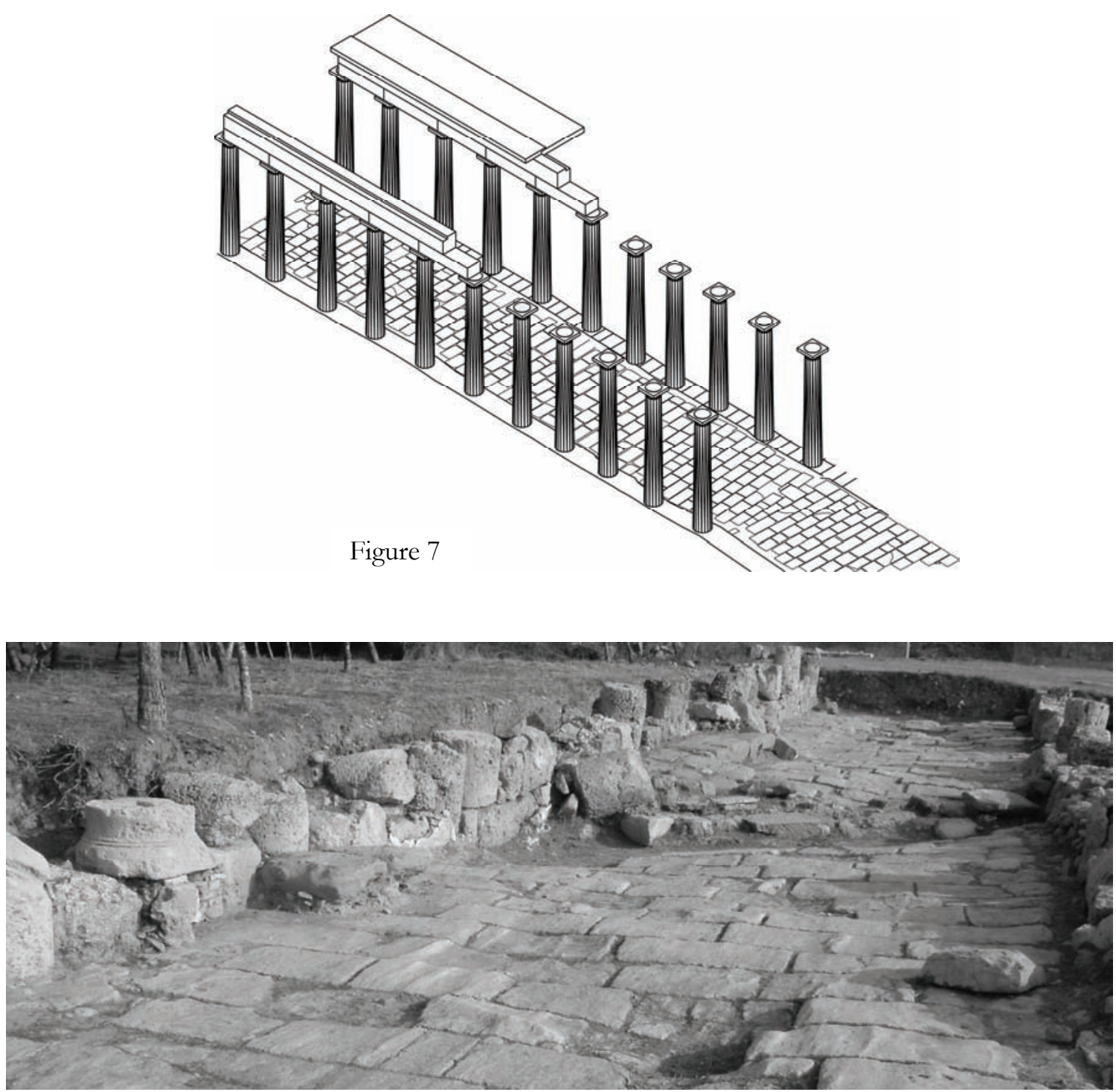

Figure 8 


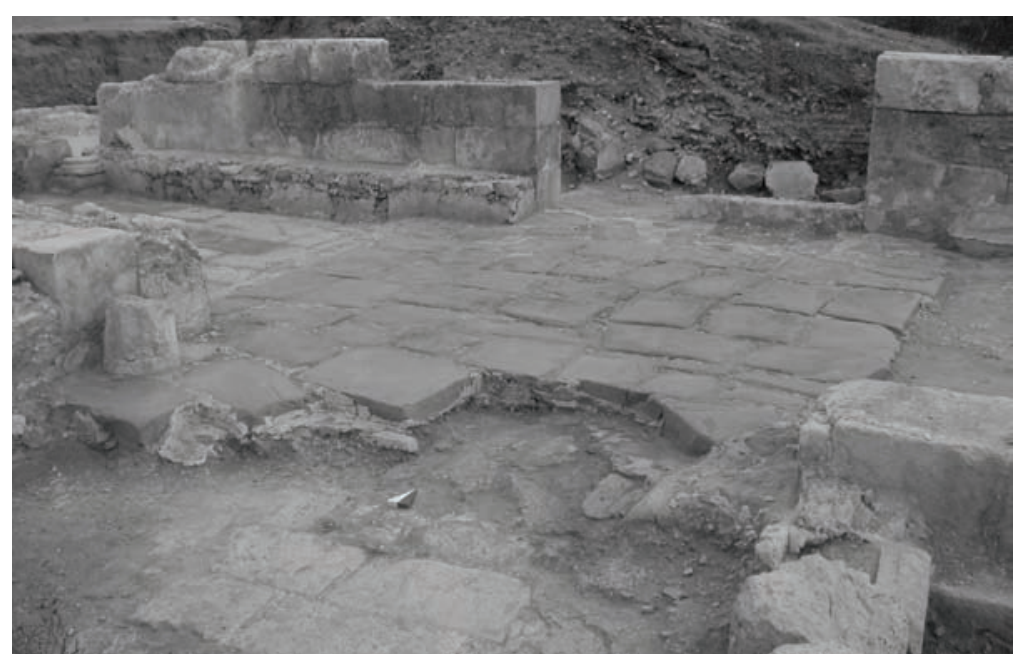

Figure 9

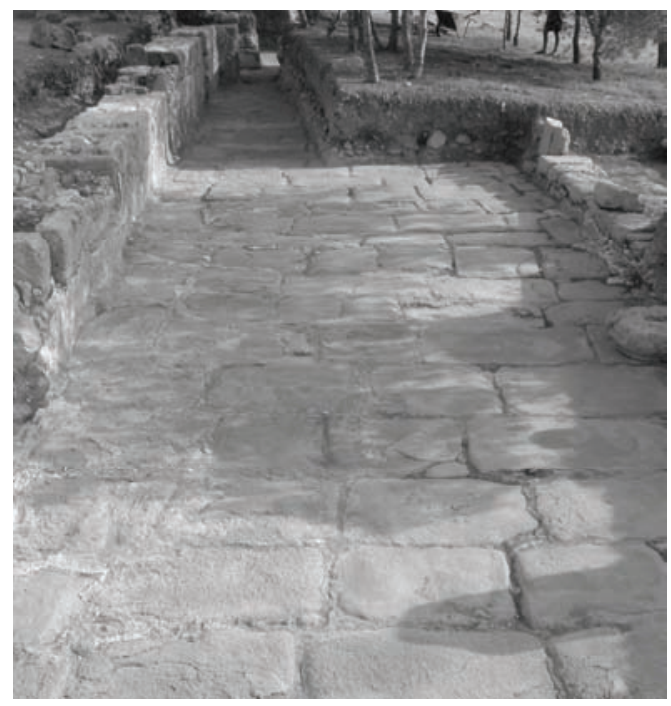

Figure 10

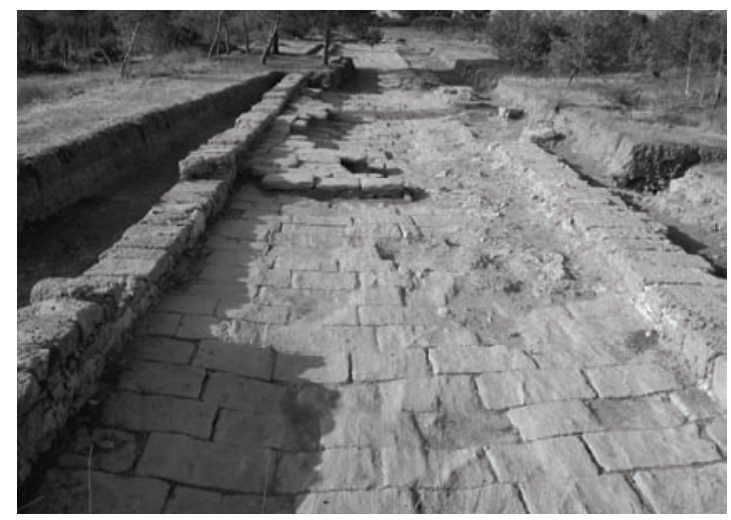

Figure 12

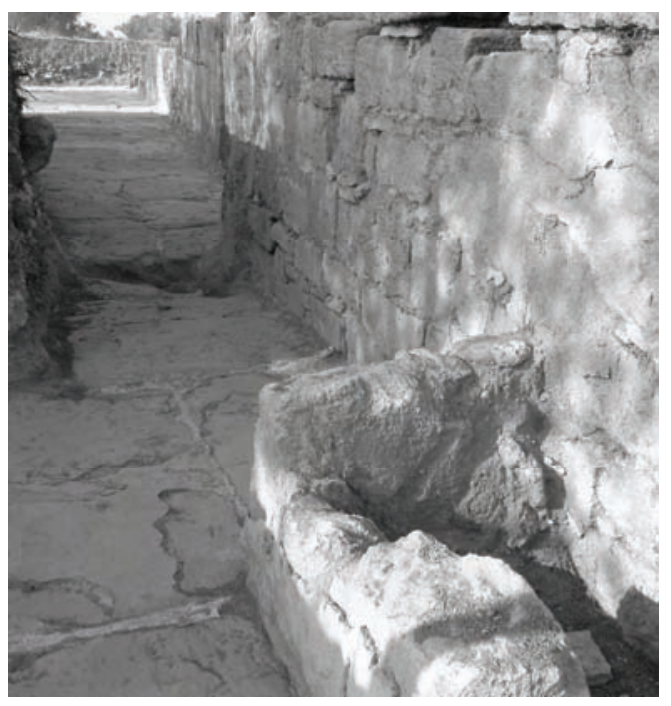

Figure 11

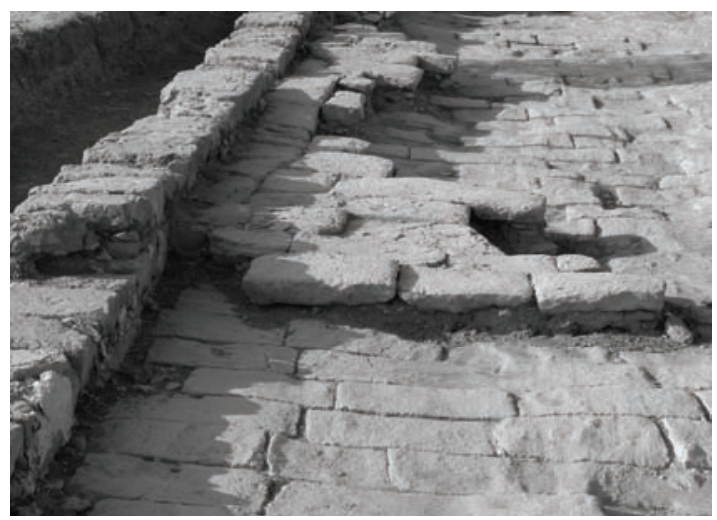

Figure 13 
Colonnaded Street at Salamis
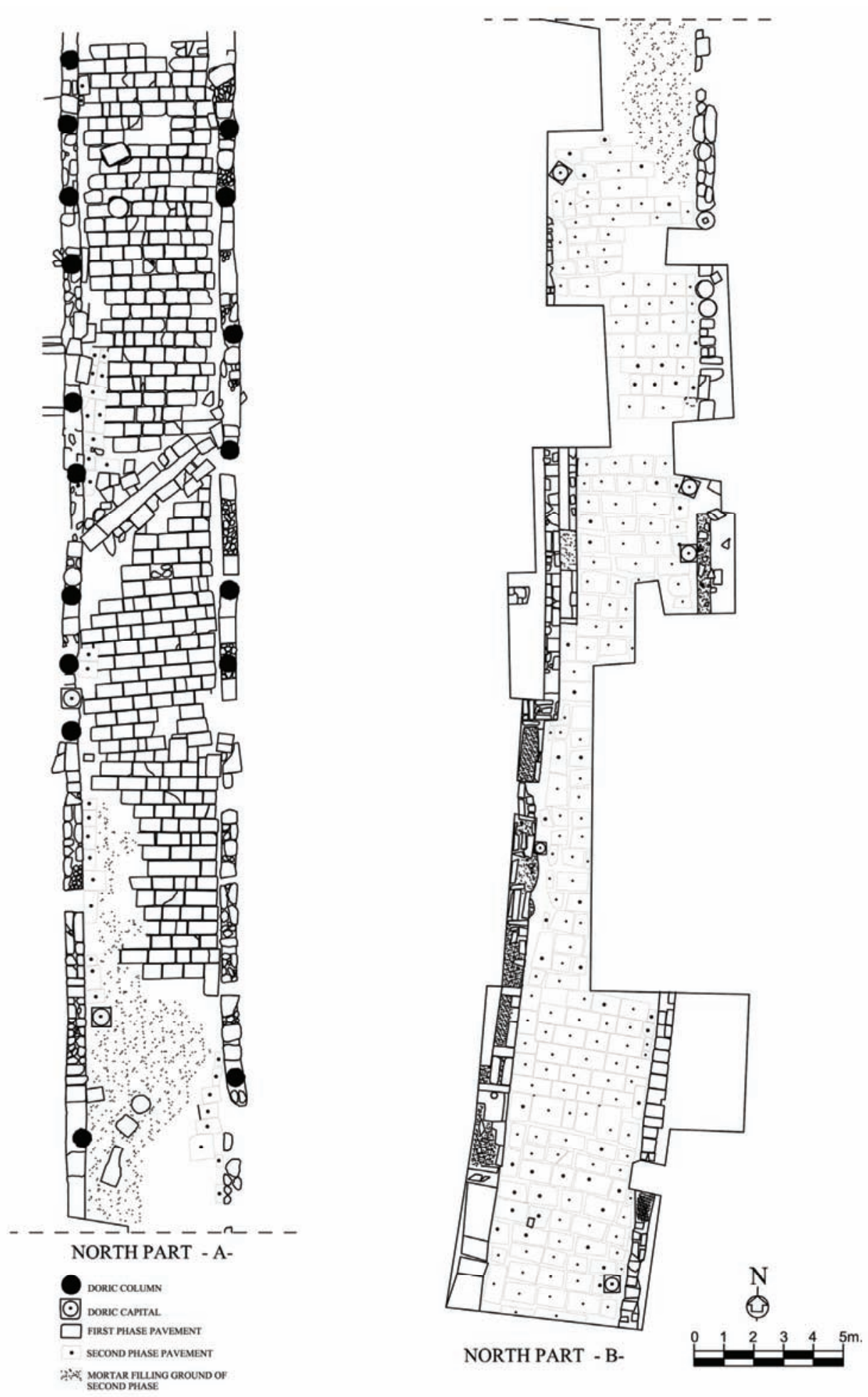

Figure 14 

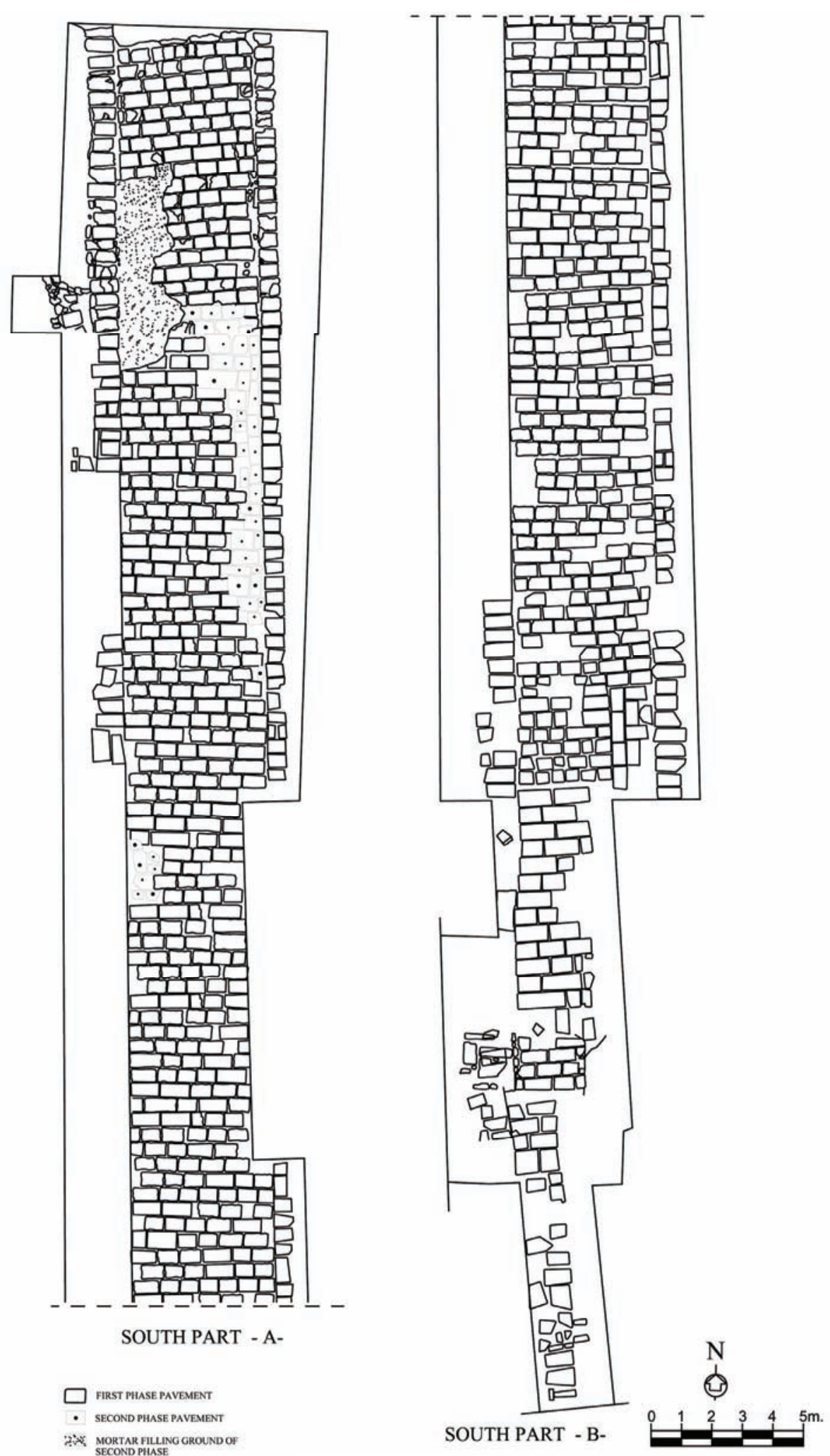

Figure 15 


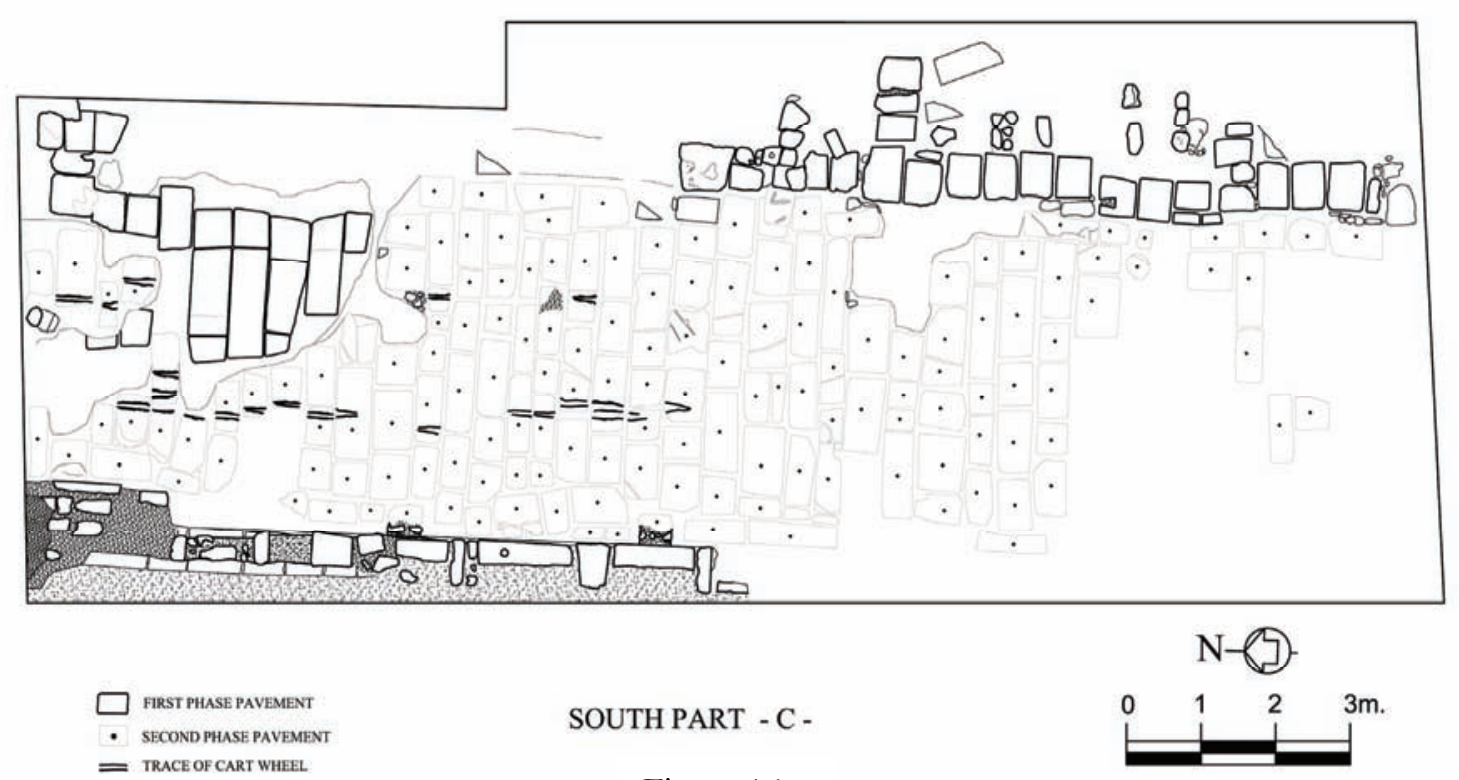

Figure 16
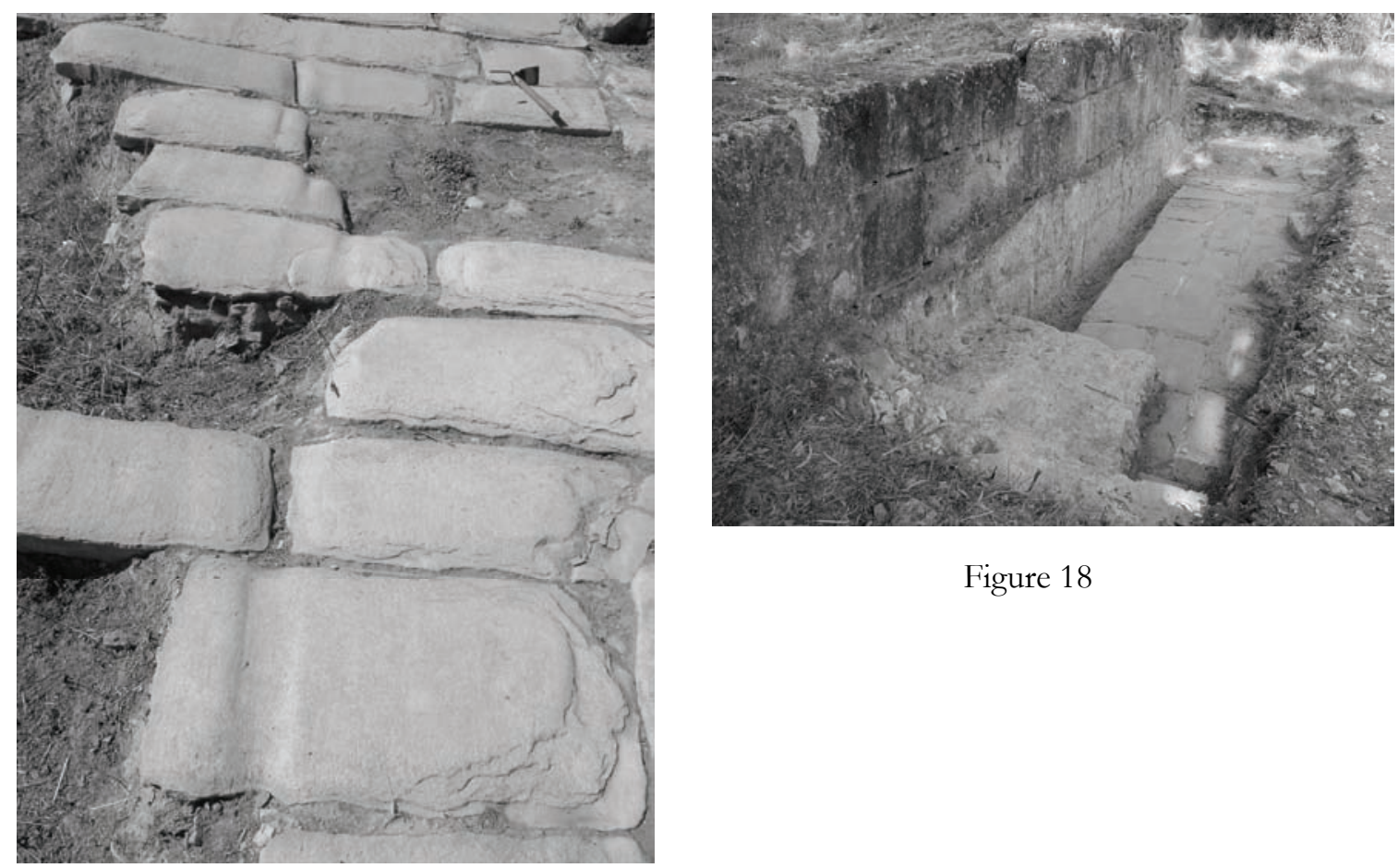

Figure 18

Figure 17 